\title{
Ultrastructural and Photosynthetic Response of Populus 107 Leaves to Cadmium Stress
}

\author{
Wei Ge ${ }^{1,2}$, Yunqiu Jiao ${ }^{1,3}$, Jinhua Zou ${ }^{1}$, Wusheng Jiang ${ }^{1}$, Donghua Liu ${ }^{1 *}$ \\ 'Tianjin Key Laboratory of Animal and Plant Resistance, College of Life Sciences, Tianjin Normal University, \\ Tianjin 300387, People's Republic of China \\ ${ }^{2}$ Key Laboratory of Bamboo and Rattan Science and Technology of the State Forestry Administration, \\ International Centre for Bamboo and Rattan, Beijing 100102, People's Republic of China \\ ${ }^{3}$ Tianjin No. 7 Junior and Senior High School, Tianjin 300160, People's Republic of China
}

Received: 13 April 2014

Accepted: 8 July 2014

\begin{abstract}
As Populus 107 is an efficient phytoextraction plant, it was used in the present investigation in order to better understand the mechanisms of detoxification and tolerance of $\mathrm{Cd}$. Cd-induced impacts on photosynthetic parameters (chlorophyll content, soluble protein, and chlorophyll fluorescence) and ultrastructural changes in leaves of Populus 107 exposed to $50 \mu \mathrm{M}, 100 \mu \mathrm{M}$, and $500 \mu \mathrm{M}$ for 40 days were carried out. The results showed that in the Cd-treated cells, almost all the chloroplasts seemed to be affected. Cd induced several significant ultrastructural changes, including swollen chloroplast thylakoids, dissolved thylakoid grana, disintegrated chloroplasts, and numerous plastoglobuli in chloroplasts. Data from chlorophyll fluorescence showed that $\mathrm{F}_{\mathrm{v}} / \mathrm{F}_{\mathrm{m}}, \mathrm{F}_{\mathrm{v}}{ }^{\prime} / \mathrm{F}_{\mathrm{m}}$, ФPSII, ETR, and $\mathrm{qP}$ decreased while $\mathrm{qN}$ increased in leaves of Populus 107 exposed to $\mathrm{Cd}$ when compared to control. The content of soluble protein increased with increasing $\mathrm{Cd}$ concentration and declined with prolonged duration of treatment. The soluble protein content in leaves treated with $50 \mu \mathrm{M} \mathrm{Cd}$ reached the maximum, which was $14.29 \%$ more than that of control. The content in leaves exposed to $500 \mu \mathrm{M} \mathrm{Cd}$ were only $61.76 \%$ of control. At the end of the experiment the contents of chlorophyll $a, b$, and $a+b$ of Populus 107 treated with $500 \mu \mathrm{M} \mathrm{Cd}$ decreased to the minimum, which were $47.69 \%$, $37.10 \%$, and $45.49 \%$ of control, and respectively, and significantly $(\mathrm{P}<0.05)$ lower than control. The toxic mechanisms of $\mathrm{Cd}$ are briefly explained.
\end{abstract}

Keywords: chlorophyll fluorescence parameters, chloroplast ultrastructure, photosynthesis pigments, soluble protein

\section{Introduction}

Cadmium (Cd) naturally found in low concentrations in the environment tends to accumulate to high and toxic concentrations in connection with mining and the excessive use of sewage sludge in agriculture [1]. Cd is thought to be a particularly dangerous pollutant due to its high toxicity and large solubility in water [2]. It is well known that $\mathrm{Cd}$ is one of the most important factors limiting normal

*e-mail: donghua@mail.zlnet.com.cn plant growth and can be absorbed readily by plants and accumulated in the human body through the food chain [3]. At a morphological level, an excessive amount of $\mathrm{Cd}$ causes stunted growth, root browning, leaf epinasty, chlorosis, and necroses [4]. At a cellular level, intoxication by $\mathrm{Cd}$ induces oxidative stress as evidenced by enhanced lipid peroxidation, hydrogen peroxide generation, and ion leakage [5].

As Cd is a highly reactive heavy metal and shows a high affinity toward functional groups of biomolecules [6], it interacts with various physiological processes that are 
essential for plant metabolism $[1,7,8]$. Cd has been shown to be one of the most effective inhibitors of photosynthetic activity. Some investigations have been reported that plant growth is affected under Cd stress, resulting in alteration of chlorophyll synthesis [9], transpiration and respiration processes [10], and stomatal opening [11], thus reducing photosynthesis $[12,13]$. The chloroplast is a large, complex double membrane organelle that performs the function of photosynthesis within plant cells and contains the substance chlorophyll that is essential for this process. Cd convincingly resulted in marked distortion of chloroplast ultrastructure leading to disturbed shape and inflated thylakoids [14]. Once Cd enters chloroplasts, it can disturb chloroplast function by inhibiting the enzymatic activities of chlorophyll biosynthesis, pigment - protein complexes, $\mathrm{O}_{2}$-evolving reactions of photosystem II (PSII), electron flow around photosystem I (PSI), and chloroplast structure [15-18].

Phytoremediation by using vegetation to remove, detoxify, or stabilize heavy metals is an acceptable tool for decontamination of polluted soil and water. Our previous study indicated that Populus 107 was an efficient phytoextraction plant as it had considerable ability to accumulate $\mathrm{Cd}(\mathrm{Cd}$ concentration in shoots exceeding $0.01 \%(\mathrm{w} / \mathrm{w}))$ [11]. However, few studies parallel analysis of chlorophyll fluorescence and photosynthesis parameters under $\mathrm{Cd}$ stress, and research related the effect of $\mathrm{Cd}$ on ultrastructural changes in leaves. To gain a deeper insight into Cdinduced impacts on photosynthetic parameters (chlorophyll content, soluble protein, and chlorophyll fluorescence) and ultrastructural changes in leaves of Populus 107 grown in the presence of different concentrations of $\mathrm{Cd}$, our investigation was carried out.

\section{Material and Methods}

\section{Culture Condition and Cadmium Treatment}

Populus 107 (Populus $\times$ euramericana cv.'Neva') was selected in the present investigation. Woody cuttings (15 $\mathrm{cm}$ in length and $1.5 \mathrm{~cm}$ in diameter) from 1-year old shoots were rooted in vermiculite for a month. Then they were selected for uniformity of roots and new shoots, and transferred to 1/2-strength Hoagland nutrient solution spiked with different concentrations of $\mathrm{Cd}(50 \mu \mathrm{M}, 100$ $\mu \mathrm{M}$, and $500 \mu \mathrm{M})$ and grown for 40 days. Cadmium was provided as cadmium chloride $\left(\mathrm{CdCl}_{2}\right)$. The Hoagland nutrient solution consisted of $0.75 \mathrm{mM} \mathrm{K}_{2} \mathrm{SO}_{4}, 0.65 \mathrm{mM}$ $\mathrm{MgSO}_{4}, 0.01 \mathrm{mM} \mathrm{KCl}, 0.25 \mathrm{mM} \mathrm{KH} \mathrm{PO}_{4}, 2 \mathrm{mM}$ $\mathrm{Ca}\left(\mathrm{NO}_{3}\right)_{2}, 100 \mu \mathrm{M}$ FeEDTA, $10 \mu \mathrm{M} \mathrm{H}_{3} \mathrm{BO}_{3}, 1 \mu \mathrm{M}$ $\mathrm{MnSO}_{4}, 0.1 \mu \mathrm{M} \mathrm{CuSO}_{4}, 0.05 \mu \mathrm{M}\left(\mathrm{NH}_{4}\right)_{6} \mathrm{Mo}_{7} \mathrm{O}_{4}$, and $1 \mu \mathrm{M}$ $\mathrm{ZnSO}_{4}$ [19], adjusted to $\mathrm{pH}$ 5.5. The experiments were conducted in a greenhouse under a $14 \mathrm{~h}$ photoperiod at $20 / 18^{\circ} \mathrm{C}$ (day/night), irradiation of $360 \mathrm{~W} \cdot \mathrm{m}^{-2}$ and $65-75 \%$ humidity. The solutions were constantly aerated and replaced every 10 days. All treatments were done in 5 replicates.

\section{Measurement of Soluble Protein Contents}

Measuring soluble protein content in this investigation was carried out according to Bradford's method [20] using bovine serum albumin (BSA) as a standard. The fresh roots and leaves from each treatment ( 6 seedlings) were washed in distilled water, dried, and put in a mortar with $5 \mathrm{~mL} 0.05$ $\mathrm{M}$ phosphate buffer solution (PBS) (pH 7.8) at the end of each time interval $(10 \mathrm{~d})$ of the $\mathrm{Cd}$ treatment. The homogenate was centrifuged at $10,000 \times \mathrm{g}$ for $20 \mathrm{~min}$ and the supernatant was used for analyzing soluble protein content. The soluble protein content was expressed as mg per $g$ fresh weight.

\section{Leaf Pigment Measurements}

Each leaf sample from each treatment was homogenized in $5 \mathrm{ml}$ of $80 \%$ acetone at $4^{\circ} \mathrm{C}$, and adding $5 \mathrm{ml}$ acetone to a total of $10 \mathrm{ml}$ in each tube. Tubes were stored in the dark at $4^{\circ} \mathrm{C}$ for $12 \mathrm{~h}$ prior to spectrophotometer measurements. Pigmentation of the sample was centrifuged $(4,000 \mathrm{~g})$ for determination. Absorbance was measured at 646 and $663 \mathrm{~nm}$ with a UV-Vis spectrophotometer (UV2550, Shimadzu, Kyoto, Japan). Chlorophyll $a\left(C_{a}\right)$ and chlorophyll $b\left(C_{b}\right)$ concentrations were calculated according to Zarco-Tejada et al. [21]:

$$
\begin{gathered}
C_{a}[\mathrm{mg} / \mathrm{g} \text { fresh matter }]= \\
{\left[12.21 \cdot \mathrm{A}_{663}-2.81 \cdot \mathrm{A}_{646}\right] \cdot \mathrm{mL} \text { Acetone } / \mathrm{mg} \text { fresh matter }} \\
C_{b}[\mathrm{mg} / \mathrm{g} \text { fresh matter }]= \\
{\left[20.13 \cdot \mathrm{A}_{646}-5.03 \cdot \mathrm{A}_{663}\right] \cdot \mathrm{mL} \text { Acetone } / \mathrm{mg} \text { fresh matter }}
\end{gathered}
$$

\section{Measurements of Chlorophyll Fluorescence}

Chlorophyll fluorescence quenching analysis was carried out at room temperature with a portable fluorometer (LI-6400, LI-COR, Lincoln, USA). Leaves were darkened for $12 \mathrm{~h}$ prior to measurement. The initial $\mathrm{Chl}$ fluorescence intensity of the dark-adapted samples $\left(\mathrm{F}_{0}\right)$ was obtained upon excitation with a weak measuring beam $(0.08 \mu \mathrm{mol}$ photons $\left.\mathrm{m}^{-2} \cdot \mathrm{s}^{-1}\right)$. Maximum fluorescence $\left(\mathrm{F}_{\mathrm{m}}\right)$ was determined following a saturating red light $(7200 \mu \mathrm{mol}$ photons $\left.\mathrm{m}^{-2} \cdot \mathrm{s}^{-1}\right)$. Yield of variable fluorescence $\left(\mathrm{F}_{\mathrm{v}}\right)$ was calculated as $\mathrm{F}_{\mathrm{m}}-\mathrm{F}_{0}$, and maximum efficiency of PSII photochemistry in the dark-adapted state as $\mathrm{F}_{\mathrm{v}} / \mathrm{F}_{\mathrm{m}}=\left(\mathrm{F}_{\mathrm{m}}-\mathrm{F}_{0} / \mathrm{F}_{\mathrm{m}}\right)$. Efficiency of energy harvesting by open reaction centers of photosystem II for light-adapted leaves were calculated as: $\mathrm{F}_{\mathrm{v}}{ }^{\prime} / \mathrm{F}_{\mathrm{m}}{ }^{\prime}=\left(\mathrm{F}_{\mathrm{m}}{ }^{\prime}-\mathrm{F}_{0}{ }^{\prime}\right) / \mathrm{F}_{\mathrm{m}}{ }^{\prime}$, where $\mathrm{F}_{0}{ }^{\prime}$ is minimal fluorescence of a momentarily darkened leaf, and $\mathrm{F}_{\mathrm{m}}$ ' is maximal fluorescence during a saturating flash light of $>7 \mathrm{mmol} \mathrm{m} \mathrm{m}^{-2} \cdot \mathrm{s}^{-1}$. Photochemical quenching $\left(\mathrm{q}_{\mathrm{p}}\right)$ was calculated as indicated by the manufacturer's manual for the LI-6400 leaf chamber fluorometer, $\mathrm{q}_{\mathrm{p}}=\left(\mathrm{F}_{\mathrm{m}}{ }^{\prime}-\mathrm{F}_{\mathrm{s}}\right) /\left(\mathrm{F}_{\mathrm{m}}{ }^{\prime}-\mathrm{F}_{0}{ }^{\prime}\right)$, where $\mathrm{F}_{\mathrm{s}}$ is the Chl fluorescence yield during actinic illumination. Other fluorescence parameters were measured on light-adapted leaves using the equations of Genty et al. [22]. The quantum yield of PSII electron transport, ФPSII $=\left(\mathrm{F}_{\mathrm{m}}{ }-\mathrm{F}_{\mathrm{s}}\right) / \mathrm{F}_{\mathrm{m}}$. The appar- 
ent electron transport rate, $\mathrm{ETR}=\left(\mathrm{F}_{\mathrm{m}}{ }^{\prime}-\mathrm{F}_{\mathrm{s}}\right) / \mathrm{F}_{\mathrm{m}}{ }^{\prime} \times$ $\mathrm{PPFD} \times 0.5 \times 0.84$ [23], Non-photochemical quenching, $\mathrm{qN}=1-\left(\mathrm{F}_{\mathrm{m}}{ }^{\prime}-\mathrm{F}_{0}{ }^{\prime}\right) /\left(\mathrm{F}_{\mathrm{m}}-\mathrm{F}_{0}\right)$. For the calculation of ETR, PPFD was the photosynthetic photon flux density of actinic illumination, 0.5 was assumed as the fraction of the excitation energy distributed to PSII, and 0.84 as the fractional light absorption of the leaf. These data were collected every 10 days.

\section{Transmission Electron Microscopy}

The leaf samples of the middle area of leaf blades from control and the treated groups grown for 40 days were hand cut with a razor blade into $1 \mathrm{~mm}^{2}$ pieces and fixed in a mixture of $2 \%$ formaldehyde and $2.5 \%$ glutaraldehyde in $0.2 \mathrm{M}$ phosphate buffer ( $\mathrm{pH}$ 7.2) for $2 \mathrm{~h}$ and then thoroughly washed with the same buffer three times. This was followed by post-fixation with $2 \%$ osmium tetroxide in the same buffer for $2 \mathrm{~h}$. They were dehydrated in an acetone series, and embedded in Spurr's ERL resin [24]. For ultrastructural observations, ultrathin sections of 75-nm thickness were cut on an ultramicrotome (Leica EM UC6, Germany) with a diamond knife, and were mounted in copper grids with 300 square mesh. The sections were stained with $2 \%$ uranyl acetate for $50 \mathrm{~min}$. and lead citrate for $15 \mathrm{~min}$. Observation and photography were accomplished by transmission electron microscopy (JEM-1230, Joel Ltd, Tokyo, Japan).

\section{Statistical Analysis}

Analysis of variance of the data was done with SigmaPlot 8.0 software. For statistical analysis, one-way analysis of variance (ANOVA) and t-test were used to determine the significance at $\mathrm{P}<0.05$. All treatments were done in five replicates.

\section{Results}

\section{Effects of Cd on Soluble Protein Contents}

The effects of $\mathrm{Cd}$ on soluble protein contents are presented in Fig. 1. The results indicated that soluble protein contents in leaves increased significantly $(\mathrm{P}<0.05)$ on the day 20 The soluble protein content in leaves treated with 50 $\mu \mathrm{M}$ Cd reached the maximum, which was $14.29 \%$ more than that of control. The soluble protein contents in leaves exposed to $500 \mu \mathrm{M}$ were observed to decline significantly $(\mathrm{P}<0.05)$ after $30 \mathrm{~d}$ treatment. At the end of the experiment soluble protein contents in leaves exposed to $\mathrm{Cd}$ treatment were significantly lower $(\mathrm{P}<0.05)$ when compared with control. The soluble protein content in leaves exposed to $500 \mu \mathrm{M}$ Cd were only $61.76 \%$ of control.

\section{Effects of Cd on Content of Leaf Pigments}

The contents of chlorophyll $a, b$, and $a+b$ of Populus 107 after 10 to 40 day $\mathrm{Cd}$ treatments were presented in Fig. 2.
The contents of leaf pigments expose to Cd decreased significantly $(\mathrm{P}<0.05)$ when compared with control, except for the group exposed to $50 \mu \mathrm{M} \mathrm{Cd}$ on day 10 . The contents of chlorophyll of poplar 107 exposed to $50 \mu \mathrm{M} \mathrm{Cd}$ increased during 30 days and then declined with prolonging the treatment time (Figs. 2a-c). At the end of the experiment the contents of chlorophyll $a, b$, and $a+b$ of Populus 107 treated with $500 \mu \mathrm{M} \mathrm{Cd}$ decreased to the minimum, which were $47.69 \%, 37.10 \%$, and $45.49 \%$ of control, respectively, and significantly $(\mathrm{P}<0.05)$ lower than control.

\section{Effects of Cd on Chlorophyll Fluorescence}

$\mathrm{F}_{\mathrm{v}} / \mathrm{F}_{\mathrm{m}}$ in Populus 107 exposed to Cd was significantly lower $(\mathrm{P}<0.05)$ in comparison with control and represented a decreased tendency with prolonging the treatment time (Fig. 3). Fig. 4 showed the changes of fluorescence parameters in light-adapted leaves. The decrease tendency in photochemical efficiency of $\operatorname{PSII}\left(\mathrm{F}_{\mathrm{v}}{ }^{\prime} / \mathrm{F}_{\mathrm{m}}{ }^{\prime}\right)$, actual photochemical efficiency of PSII (PSII), electronic transfer rate (ETR), and photochemical quenching (qP) were observed, whereas qN had increased tendency. $\mathrm{F}_{\mathrm{v}} / \mathrm{F}_{\mathrm{m}}$, of Populus 107 exposed to $\mathrm{Cd}$ was significantly lower $(\mathrm{P}<0.05)$ during the whole treatment in comparison with control, except for the group treated with $50 \mu \mathrm{M}$ and $100 \mu \mathrm{M} \mathrm{Cd}$ on day 10 . Significant difference $(\mathrm{P}<0.05)$ was shown in PSII and ETR of Populus 107 exposed to Cd when compared with control, except for ETR on day 10. qP in control was significantly higher when compared with the treatment groups. A significant increase of $\mathrm{qN}(\mathrm{P}<0.05)$ was noted after 20 days of treatment as compared to control plants.

\section{Effect of Cd on Subcellular Structures of Leaves}

Electron microscopic observations of mesophyll chloroplasts from poplar leaves treated with $\mathrm{Cd}$ revealed distinct differences between the samples examined compared to control (Fig. 5). Under natural conditions, the

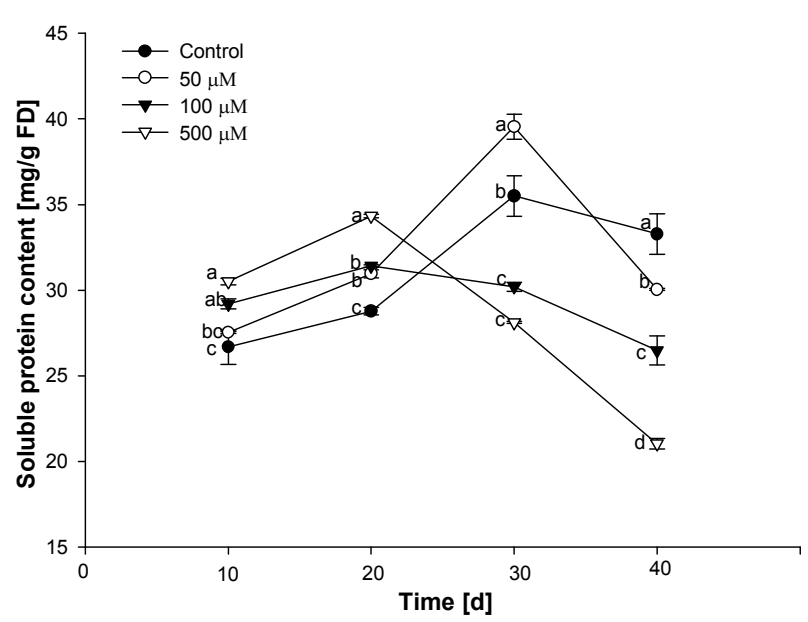

Fig. 1. Effects of different Cd concentrations on the contents of soluble protein in leaves of Populus 107 exposed to Cd stress in 40 days. Vertical bars denote $\mathrm{SE}(\mathrm{n}=3)$. Values with different letters differ significantly from each other $(\mathrm{p}<0.05$, $\mathrm{t}$-test). 
cytoarchitecture of Populus 107 leaves was intact with typical organelles. The shuttle-like or spheroid chloroplasts were abundant in normal leaf cells. Chloroplasts with a well-developed lamellar system and the grana layers were arranged in an orderly fashion. Some plastoglobuli

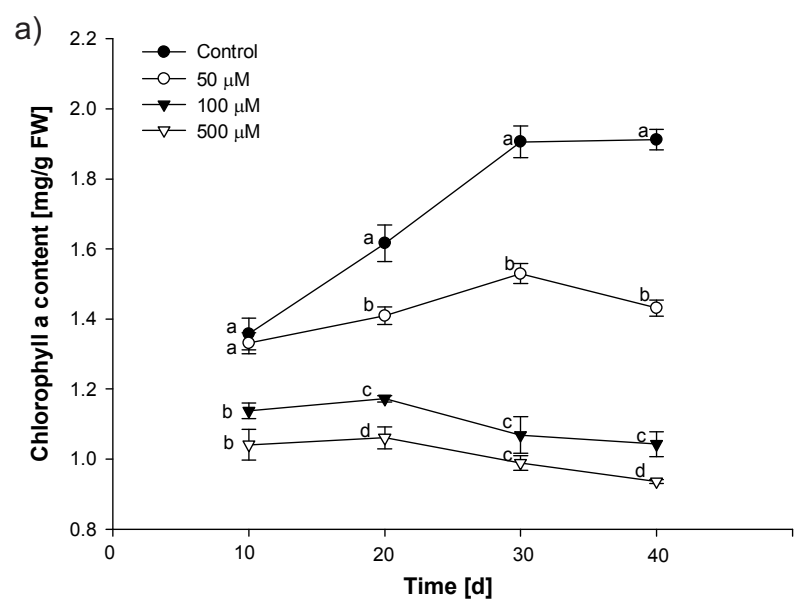

b)

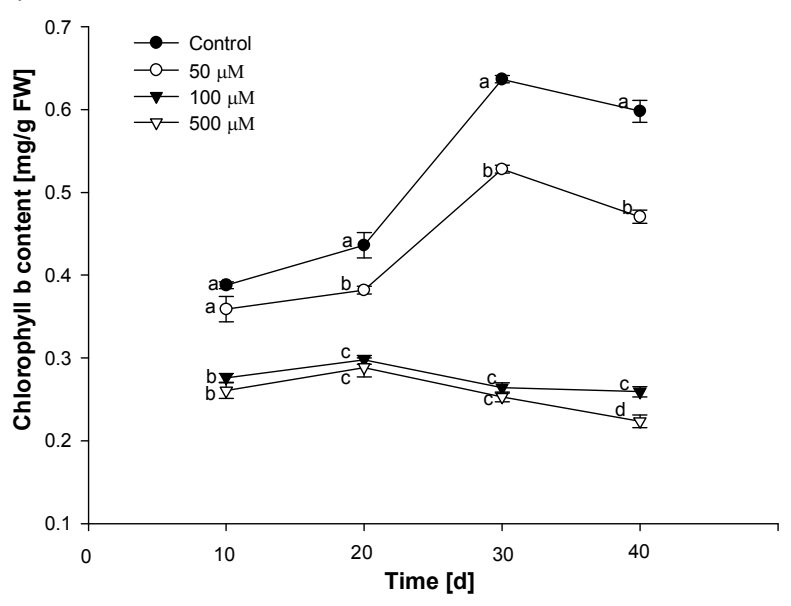

c)

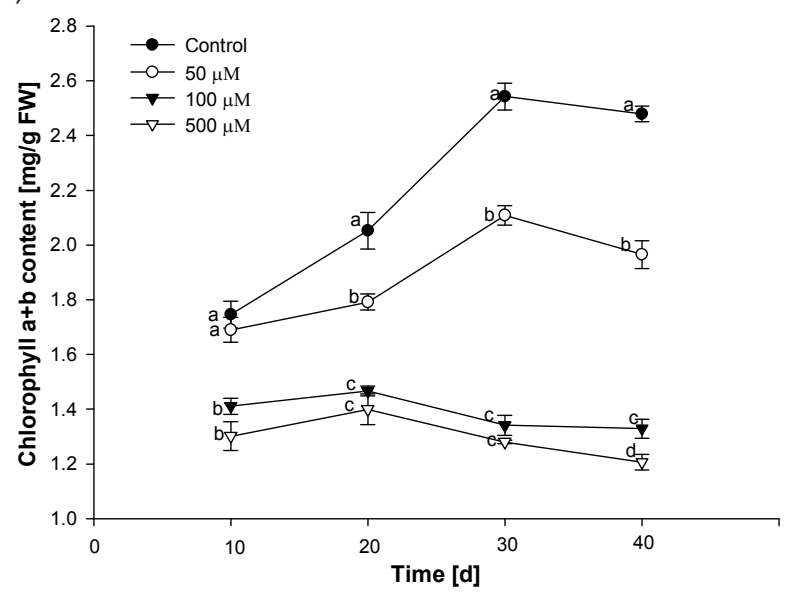

Fig. 2. Chlorophyll $a, b, a+b$ contents of Populus 107 (a, b, c) exposed to Cd stress in 40 days. Vertical bars denote $\mathrm{SE}(\mathrm{n}=3)$. Values with different letters differ significantly from each other $(\mathrm{p}<0.05, \mathrm{t}$-test $)$

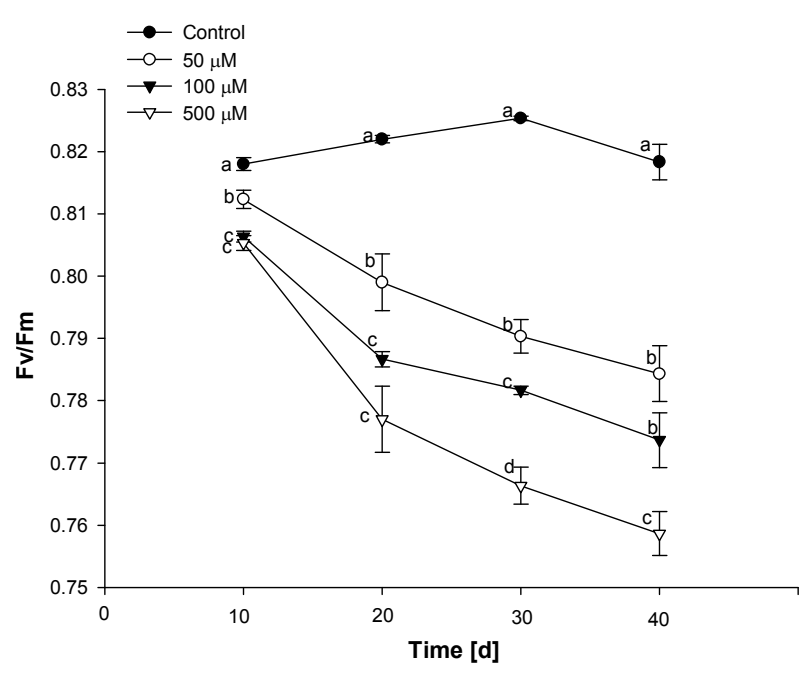

Fig. 3. Effects of $\mathrm{Cd}$ on changes of $\mathrm{F}_{\mathrm{v}} / \mathrm{F}_{\mathrm{m}}$ in Populus 107 treated with different concentrations of $\mathrm{Cd}$ in 40 days. Vertical bars denote $\mathrm{SE}(\mathrm{n}=3)$. Values with different letters differ significantly from each other $(\mathrm{p}<0.05$, $\mathrm{t}$-test $)$.

appeared in the chloroplasts (Fig. 5a). In the Cd-treated cells, almost all the chloroplasts seemed to be affected, but to different degrees. At $50 \mu \mathrm{M} \mathrm{Cd}$, most of the chloroplasts were either undamaged or only slightly damaged in comparison with control. Generally, a small proportion of thylakoid membranes were slightly disintegrated in some cells (Fig. 5b). Occasionally the outer membrane of the chloroplasts envelope was disrupted. The main alterations observed in chloroplast appearance, in $100 \mu \mathrm{M} \mathrm{Cd}$ concentrations, were that distorted chloroplasts were more common and they were rounded in shape and irregular in outline. Some cells showed strongly swollen chloroplast thylakoids (Fig. 5c). The thylakoid grana were dissolved and were hardly visible in some cells (Figs. 5d). With the further increase in $\mathrm{Cd}$ concentration $(500 \mu \mathrm{M})$, the toxic symptoms of chloroplasts were more significant because chloroplasts in the cell decreased obviously in number and the breakages occurred in the membrane of some chloroplasts (Fig. 6a). The thylakoid grana were damaged and disappeared, and chloroplasts disintegrated (Fig. 6b). Plastoglobuli were more numerous in chloroplasts and large inter-thylakoidal spaces in the stroma were lightly stained (Fig. 6c).

\section{Discussion}

Soluble protein content in organisms is an important indicator of reversible and irreversible changes in metabolism and responds to a wide variety of stressor $[25,26]$. The results indicated that the soluble protein content in leaves of Populus 107 exposed to $\mathrm{Cd}$ increased with increasing $\mathrm{Cd}$ concentration and declined with prolonging duration of treatment. We think that there are two reasons why $\mathrm{Cd}$ induces the high soluble protein content. First of all, $\mathrm{Cd}$ induces the expression of several genes and increases the synthesis of several proteins. In addition, a high concentra- 
tion of heavy metal treatment induces the production of heavy metal-resistance proteins. They could resist the toxicity of heavy metal [27]. During the later period of treatment, the decline of soluble protein contents could be explained that the $\mathrm{Cd}$-induced oxidative stress appeared
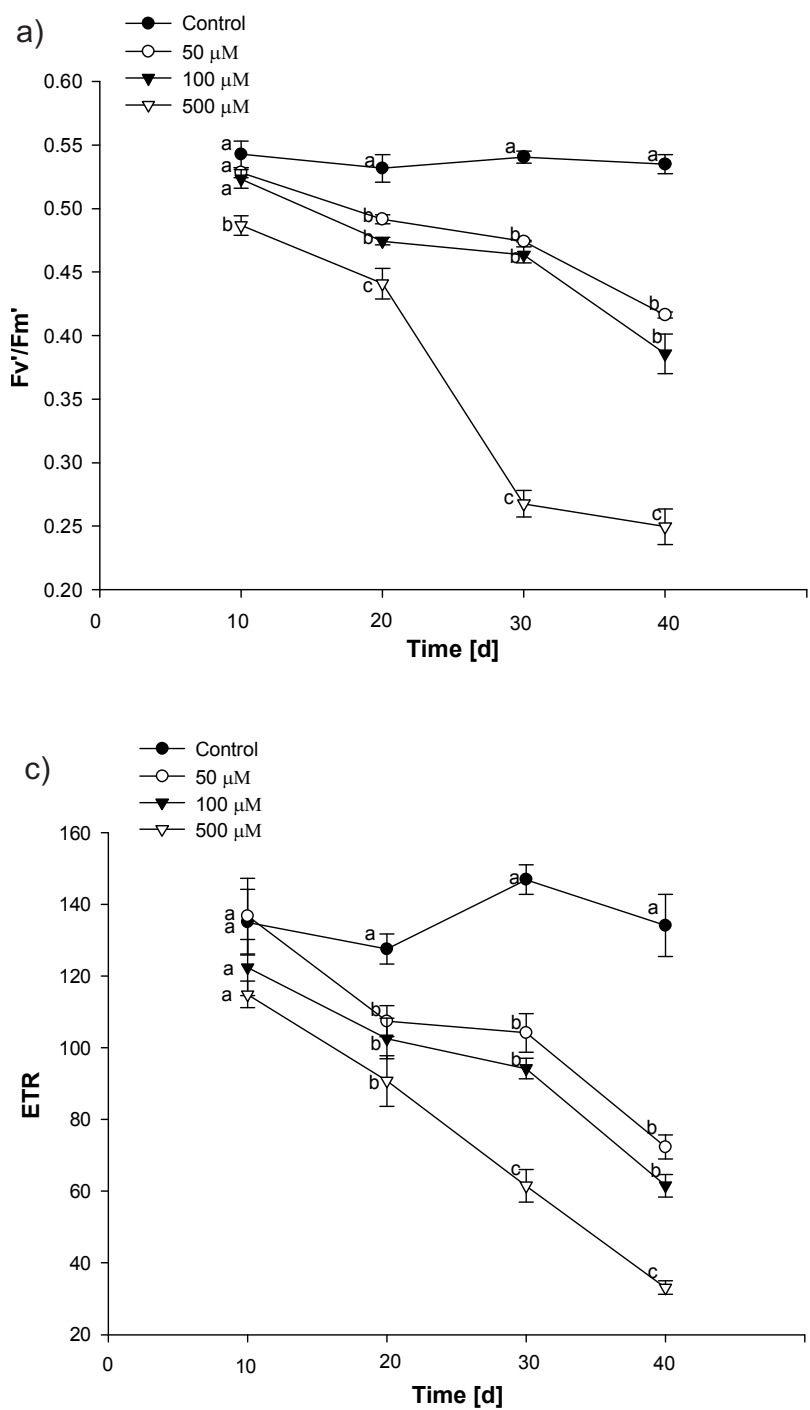

[26] and the protein synthesizing machinery was impaired due to the Cd effect [28]. Reactive oxygen species (ROS) can affect protein functions through multiple mechanisms, including regulation of protein expression, post-translational modifications, and alteration of protein stability [29]. Cd
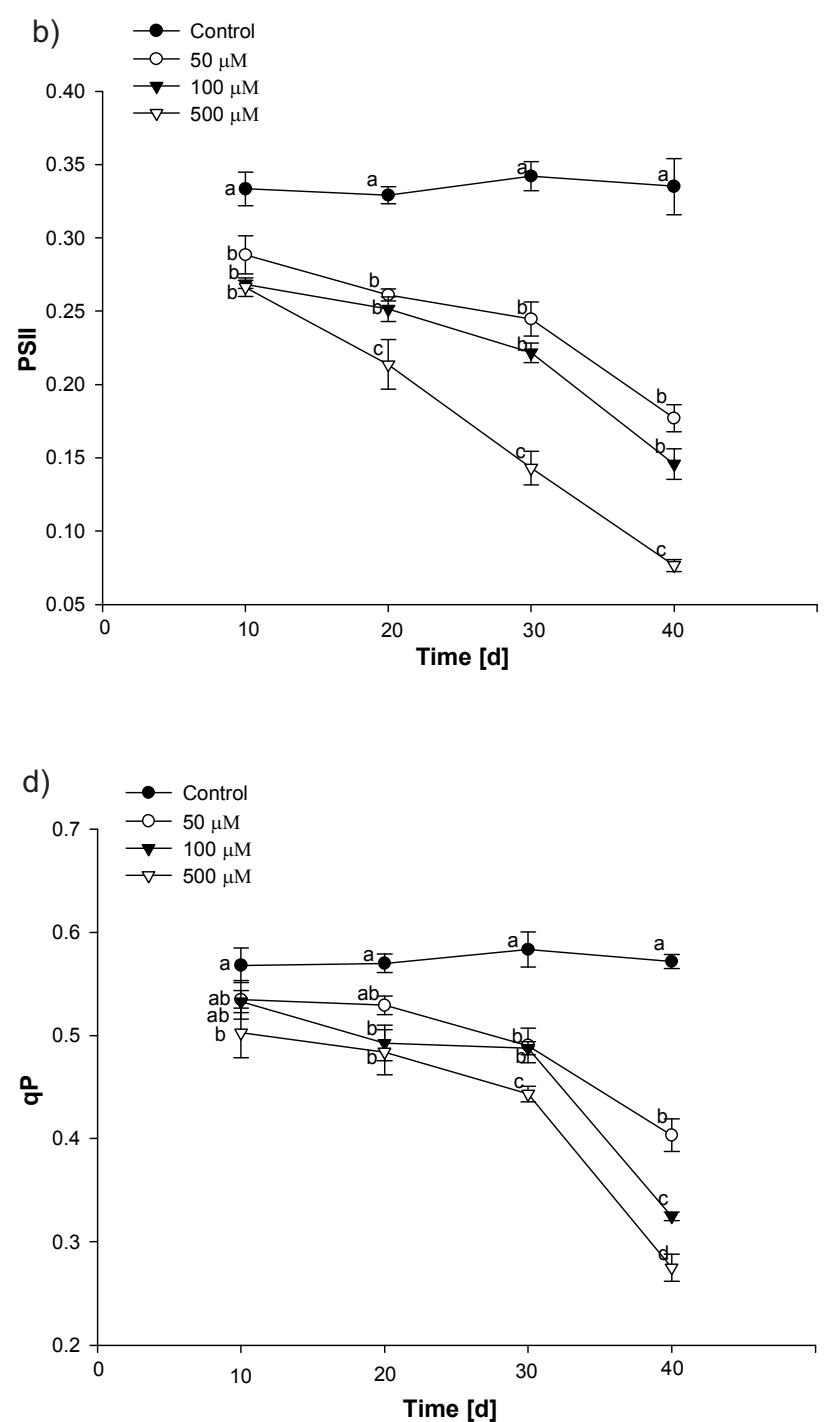

e)

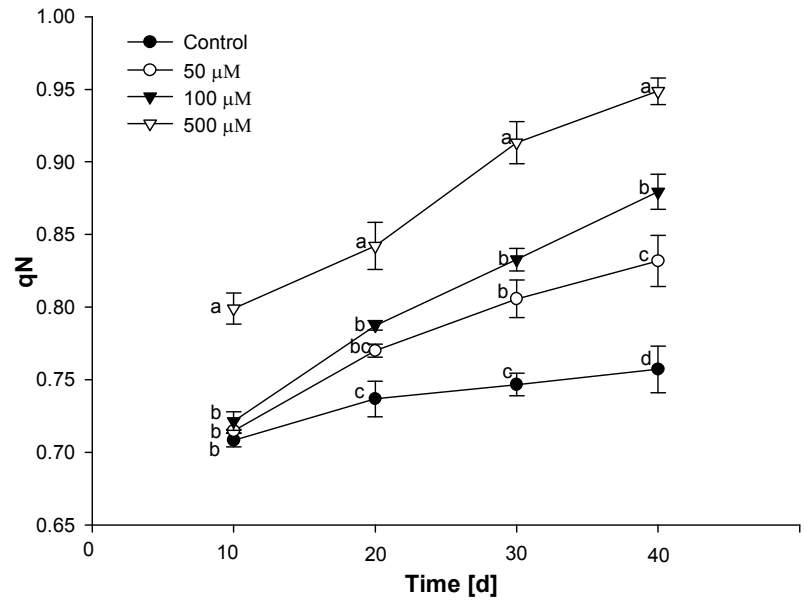

Fig. 4. Effects of $\mathrm{Cd}$ on changes of $\mathrm{F}_{\mathrm{v}}{ }^{\prime} / \mathrm{F}_{\mathrm{m}}{ }^{\prime}$, PSII, ETR, $\mathrm{qP}, \mathrm{qN}$ in Populus 107 treated with different concentrations of $\mathrm{Cd}$ in 40 days. Values with different letters differ significantly from each other $(\mathrm{p}<0.05$, t-test). 
can affect the absorption of several important nutrition elements and stop some significant physiological material from synthesizing, so some physiological index declined and the biomass decreased (data unpublished).

Chlorophyll is a major pigment in the photosynthesis process, whose content and $\mathrm{a} / \mathrm{b}$ value are an indication of the activity of photosynthesis. It is well known that photosynthesis is especially sensitive to the presence of $\mathrm{Cd}$ in chloroplasts [30, 31]. Cd could interfere with the whole photosynthetic process, from chlorophyll biosynthesis and degradation, assembly of pigment protein complexes and thylakoids, to the electron transport chain, the Calvin cycle enzymes, and sugar transport and consumption [32]. It has long been known that interveinal chlorosis of leaves is one of the firstly visible symptoms of Cd toxicity and that it is due to decreased rate of chlorophyll biosynthesis and chlorophyll content caused by damages to thylacoid membranes. The results from the present investigation indicated that the amounts of chlorophyll $a$, chlorophyll $b$, and, consequently, total chlorophylls were lower than those in control plants, which is in agreement with the findings of Pietrini et al. [33] and Shen et al. [34] in poplar. Nada et al. indicated that $\mathrm{Cd}$ could induce Fe deficiency in almond seedlings exposed to $25,50,100,150 \mu \mathrm{M} \mathrm{Cd}$, which resulted in the decrease in ferredoxins necessary for the lightinduced oxido-reduction process and reduction in chlorophyll content [35]. We assume that in the present investiga- tion $\mathrm{Cd}$ induced Fe deficiency and resulted in the decrease of chlorophyll content. However, more work needs to be done in this direction. In recent years the technique of chlorophyll fluorescence has become ubiquitous in plant ecophysiology studies. Chlorophyll fluorescence depends to a great extent on pigment content and a leaf's ability to photosynthesize. Chlorophyll fluorescence parameters such as ФPSII, $\mathrm{F}_{\mathrm{v}} / \mathrm{F}_{\mathrm{m}}, \mathrm{F}_{\mathrm{v}}{ }^{\prime} / \mathrm{F}_{\mathrm{m}}{ }^{\prime}$, ФPSII, ETR, and $\mathrm{qP}$ have been established as a reliable indicator of the intensity of stress [36]. Data from the present investigation showed that $F_{v} / F_{m}$, $\mathrm{F}_{\mathrm{v}}{ }^{\prime} / \mathrm{F}_{\mathrm{m}}{ }^{\prime}$, ФPSII, ETR, and $\mathrm{qP}$ decreased, while $\mathrm{qN}$ increased. The decrease could be explained by the fact that $\mathrm{Cd}$ destroyed the reaction center of photosynthesis and restrained the photosynthesis [37]. It is commonly accepted that $\mathrm{Cd}$ ions and other heavy metals are highly reactive and affect various aspects of plant physiology [38]. Khan and Khan indicated that although Nickel and zinc were metals considered nutrients essential for plant growth and development, at high concentrations they became phytotoxic, and photosynthetic parameters were reduced significantly in plants treated with $\mathrm{Ni}$ and $\mathrm{Zn}$ when compared with control plants [39]. In different plant species heavy metals decrease carbon assimilation and can generate oxidative stress [40], which ultimately results in wilting and affects the respiration rate [41]. Pietrini et al. found that the peculiar $\mathrm{Cd}$ accumulation in small necrotic areas close to the main vein in willow and poplar clones is associated with

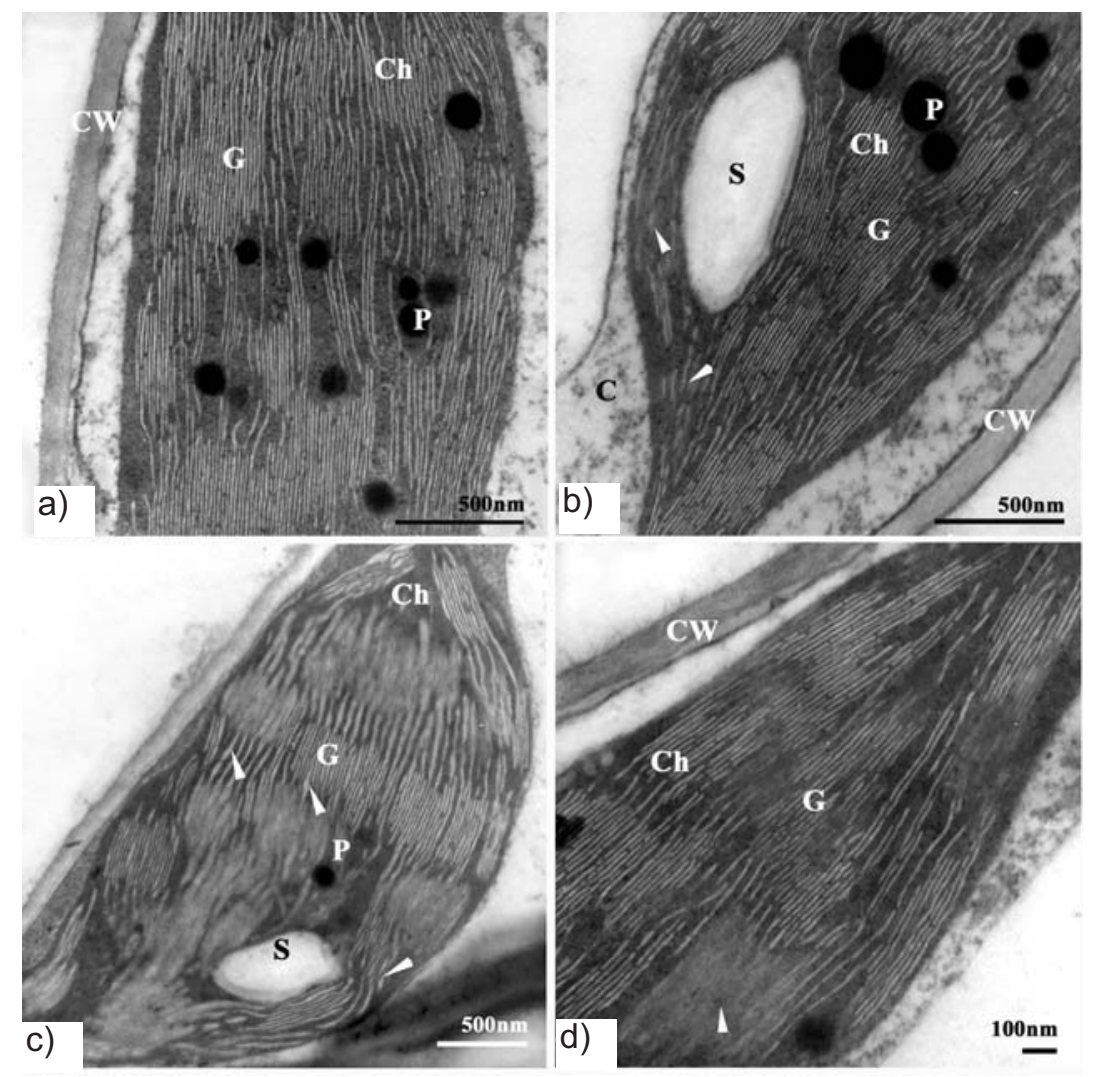

Fig. 5. TEM micrographs of chloroplasts from control and Cd-treated Populus 107. a) Chloroplasts with a well-developed lamellar system and the grana layers in control cell. b) Slightly changed chloroplast in the plant exposed to $50 \mu \mathrm{M}$ Cd. Note slightly disintegrated thylakoid membranes (arrows). c) Strongly swollen chloroplast thylakoids in plants treated with $100 \mu \mathrm{M} \mathrm{Cd}$ (arrows). d) Dissolved thylakoid grana (100 $\mu \mathrm{M} \mathrm{Cd}$; arrow).

Abbreviations: $\mathrm{C}$ - cytoplasm, $\mathrm{Ch}$ - chloroplast, $\mathrm{CW}$ - cell wall, $\mathrm{G}$ - grana stack, $\mathrm{P}$ - plastoglobuli, $\mathrm{S}$ - starch grain. 
low values of the chlorophyll fluorescence parameters $\left(\mathrm{F}_{0}\right.$, $\mathrm{F}_{\mathrm{m}}, \mathrm{F}_{\mathrm{v}} / \mathrm{F}_{\mathrm{m}}$, ФPSII, $\mathrm{qP}$, and NPQ) after the investigation, where willow and poplar clones grown in the presence of $50 \mu \mathrm{m} \mathrm{CdSO}_{4}$ for 3 weeks under hydroponic conditions were used to examine leaf gas exchange, chlorophyll fluo-

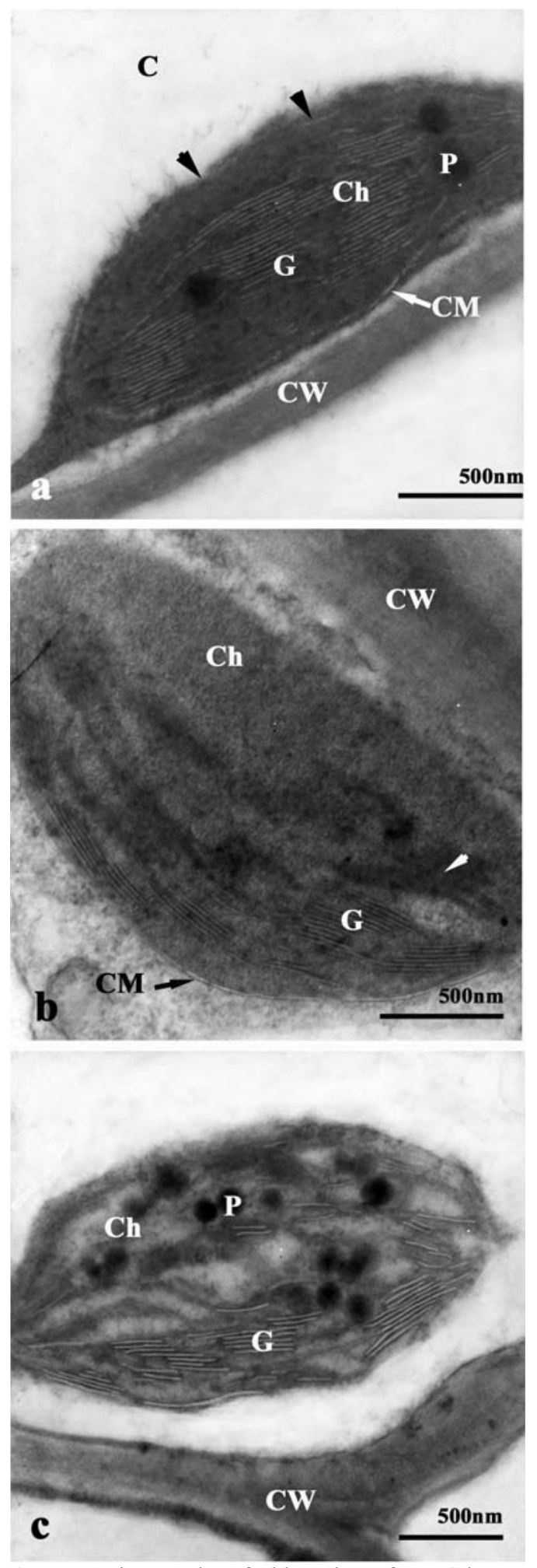

Fig. 6. TEM micrographs of chloroplasts from Cd-treated of Populus 107. a) Breakages in the membrane of chloroplasts (500 $\mu \mathrm{M} \mathrm{Cd}$, arrows). b) The damaged thylakoid grana and disintegrated chloroplasts (500 $\mu \mathrm{M} \mathrm{Cd}$, arrows). c) Damaged disintegrating chloroplasts and increased plastoglobuli $(500 \mu \mathrm{M} \mathrm{Cd})$. rescence parameters and images, and for $\mathrm{Cd}$ detection using energy dispersive X-ray fluorescence (ED-XRF). The findings supported the results in the present investigation. High fluorescence parameters $\left(\mathrm{F}_{\mathrm{v}} / \mathrm{F}_{\mathrm{m}}\right.$, FPSII, and $\mathrm{qP}$ values $)$ confirmed the absence of detectable $\mathrm{Cd}$ [42].

Choudhury and Panda [43] and Bi et al. [44] indicated that the alterations observed in the ultrastructure of the chloroplasts in leaves of plants exposed to $\mathrm{Cd}$ might be due to an increase in the production of reactive oxygen species (ROS), which in high concentration in the cellular environment can cause oxidative damage to cellular structure and function. The ultrastructural effects found in Populus 107 exposed to $\mathrm{Cd}$, even at high concentrations and prolonged periods, are mainly confined to the chloroplasts structure. Chloroplasts looked misshapen and $\mathrm{Cd}$ treatment interfered with the correct organization of the inner membrane system. The thylakoid system appeared incorrectly shaped: grana and stroma thylakoids were not clearly distinguishable. Numerous plastoglobuli distributed in the stroma under $\mathrm{Cd}$ stress is usually considered a symptom of senescence because these globules were regarded as lipid droplets from thylakoid degradation $[45,46]$. Senescence induced by $\mathrm{Cd}$ was given by the swollen thylakoids. Gallego et al. [47] indicated that senescence was induced by oxidative stress, contributing to aging of whole cells and chloroplasts, suggesting the possible peroxidation of thylakoid membranes by the lipoxygenase system. However, the effects of $\mathrm{Cd}$ on chloroplast structure differ from those induced by other heavy metals. Heavy metals were shown to induce starch accumulation, probably by inhibition of vein loading [4850]. In the present study, the absence of starch accumulation in chloroplast stroma may be explained by the inhibition of photosynthesis by $\mathrm{Cd}$ [51-53].

\section{Conclusion}

Alterations in ultrastructure and photosynthetic parameters would occur before any visible symptom of toxicity appears, and the endpoint based on these parameters might be more sensitive or indicative than morphological observation in revealing eco-toxicity of $\mathrm{Cd}$. Our previous results indicated that Populus 107 tolerated high concentrations of $\mathrm{Cd}$ and have an ability to take up it from treatment medium [54]. In view of their fast growth, high biomass, and adequate $\mathrm{Cd}$ tolerant system, Populus 107 appears to have great potential for remediation purposes. Future research is needed to analyze the potential of Populus 107 to accumulate $\mathrm{Cd}$ from contaminated soils in non-laboratory environments. Besides, a better understanding of the mechanistic details of Cd detoxification in Populus 107 may lead to engineering of these plants to enhance their $\mathrm{Cd}$ phytoremediation capacity.

\section{Acknowledgements}

This project was supported by the National Natural Science Foundation of China. The authors wish to express their appreciation to the reviewers for this paper. 


\section{References}

1. DALCORSO G., FARINATI S., MAISTRI S., FURINI A. How plants cope with cadmium: staking all on metabolism and gene expression. J. Integr. Plant Biol. 50, 1268, 2008.

2. PINTO A.P., MOTAA.M., DE VARENNES A., PINTO F.C. Influence of organic matter on the uptake of cadmium, zinc, copper and iron by sorghum plants. Sci. Total Environ. 326, 239, 2004.

3. JÄRUP L., AKESSSON A. Current status of cadmium as an environmental health problem. Toxicol Appl. Pharm. 238, 201, 2009.

4. BENAVIDES M.P., GALLEGO S.M., TOMARO M.L. Cadmium toxicity in plants. Braz. J. Plant Physiol. 17, 21, 2005.

5. FERNANDEZ-OCANA A., CHAKI M., LUQUE F., GOMEZ-RODRIGUEZ M.V., CARRERAS A., VALDERRAMA R., BEGARA-MORALES J.C., HERNANDEZ L.E., CORPAS F.J., BARROSO J.B. Functional analysis of superoxide dismutases (SODs) in sunflower under biotic and abiotic stress conditions. Identification of two new genes of mitochondrial Mn-SOD. J. Plant Physiol. 168, 1303, 2011.

6. MENDOZA-CÓZATL D., LOZA-TAVERA H., HERNANDEZ-NAVARRO A., MORENO-SANCHEZ R. Sulfur assimilation and glutathione metabolism under cadmium stress in yeast, protists and plants. FEMS Microbiol. Rev. 29, 653, 2005.

7. EKMEKCI Y., TANYOLAC D., AYHAN B. Effects of cadmium on antioxidant enzyme and photosynthetic activities in leaves of two maize cultivars. J. Plant Physiol. 165, 600, 2008.

8. HE J.Y., REN Y.F., ZHU C., YAN Y.P., JIANG D.A. Effect of $\mathrm{Cd}$ on growth, photosynthetic gas exchange, and chlorophyll fluorescence of wild and Cd-sensitive mutant rice. Photosynthetica, 46, 466, 2008.

9. GILL SS., KHAN NA., TUTEJA N. Cadmium at high dose perturbs growth, photosynthesis and nitrogen metabolism while at low dose it up regulates sulfur assimilation and antioxidant machinery in garden cress (Lepidum sativum L.). Plant Sci. 182, 112, 2012.

10. HASAN S.A., HAYAT S., ALI B., AHMAD A. 28Homobrassinolide protects chickpea (Cicer arietinum) from cadmium toxicity by stimulating antioxidants. Environ. Pollut. 151, 60, 2008.

11. SANDALIO L.M., DALURZO H.C., GOMEZ M., ROMERO-PUERTAS M.C., del RÍO L.A. Cadmiuminduced changes in the growth and oxidative metabolism of pea plants. J. Exp. Bot. 52, 2115, 2001.

12. MONTEIRO M.S., SANTOS C., SOARES A.M.V.M., MANN R.M. Assessment of biomarkers of cadmium stress in lettuce. Ecotoxicol. Environ. Saf. 72, 811, 2009.

13. DIAS MC., MONTEIRO C., MOUTINHO-PEREIRA J., CORREIA C., GONÇALVES B., SANTOS C. Cadmium toxicity affects photosynthesis and plant growth at different levels. Acta Physiol. Plant. 35, 1281, 2013.

14. NAJEEB U., JILANIC G., ALIA S., SARWARD M., XUA L., ZHOUA W. Insights into cadmium induced physiological and ultra-structural disorders in Juncus effusus L. and its remediation through exogenous citric acid. J. Hazard. Mater. 186, 565, 2011.

15. BAZZAZ F.A., ROLFE G.L., CARLSON R.W. Effect of $\mathrm{Cd}$ on photosynthesis and transpiration in excised leaves of cornand sunflower. Plant Physiol. 32, 373, 1974.
16. HAMPP R., BEULICH K., ZIEGLER H. Effects of zinc and cadmium on photosynthetic $\mathrm{CO}_{2}$-fixation and Hill activity of isolated spinach chloroplasts. Z. Pflanzenphysiol. 77, 336, 1976.

17. SIEDLECKA A., KRUPA Z., SAMUELSSON G., OEQUIST G., GARDESTROEM P. Primarycarbon metabolism in Phaseolus vulgaris plants under $\mathrm{Cd}(\mathrm{II}) / \mathrm{Fe}$ interaction. Plant Physiol. Biochem. 35, 951, 1997.

18. YING R.R., QIU R.L., TANG Y.T., HUA P.J., QIU H., CHEN H.R., SHI T.H., MOREL J.L. Cadmium tolerance of carbon assimilation enzymes and chloroplast in $\mathrm{Zn} / \mathrm{Cd}$ hyperaccumulator Picris divaricata. J. Plant Physiol. 167, $81,2010$.

19. STEPHAN U.W., PROCHAZKA Z. Physiological disorders of the nicotianamine-auxotroph tomato mutant chloronerva at different levels of iron nutrition. I. Growth characteristics and physiological abnormalities as related to iron and nicotianamine supply. Acta Bot. Neerl. 38, 147, 1989.

20. BRADFORD M.M. A rapid and sensitive method for the quantitation of microgram quantities of protein utilizing the principle of proteindye binding. Anal. Biochem. 72, 248, 1976.

21. ZARCO-TEJADA P.J., BERJÓN A., LÓPEZ-LOZANO R., MILLER J.R., MARTÍN P., CACHORRO V., GONZÀLEZ M.R., DE FRUTOS A. Assessing vineyard condition with hyperspectral indices: leaf and canopy reflectance simulation in a row-structured discontinuous canopy. Remote Sens. Environ. 99, 271, 2005.

22. GENTY B., BRIANTAIS J.M., BAKER N.R. The relationship between the quantum yield of photosynthetic electron transport and quenching of chlorophyll fluorescence. Biochem. Biophys. Acta 99, 87, 1989

23. SOUZA R.P., MACHADO E.C., SILVA J.A.B., LAGOA A.M.M.A., SILVEIRA J.A.G. Photosynthetic gas exchange, chlorophyll fluorescence and some associated metabolic changes in cowpea (Vigna unguiculata) during water stress and recovery. Environ. exp. Bot. 51, 45, 2004.

24. SPURR A.R. A low-viscosity epoxy resin embedding medium for electron microscopy. J. Ultra. Res. 26, 31, 1969.

25. SINGH P.K., TEWARI R.K. Cadmium toxicity induced changes in plant water relations and oxidative metabolism of Brassica juncea L. plants. J. Environ. Biol. 24, 107, 2003.

26. AIBIBU N., LIU Y.G., ZENG G.M., WANG X., CHEN B.B., SONG H.X., XUA LI. Cadmium accumulation in vetiveria zizanioides and its effects on growth, physiological and biochemical characters. Bioresource Technol. 101, 6297, 2010

27. YANG Q.S., WANG Y.Q., ZHANG J.J., SHI W., QIAN C., PENG X. Identification of aluminum-responsive proteins in rice roots by a proteomic approach: Cysteine synthase as a key player in Al response. Proteomics, 7, 737, 2007.

28. JIANG H.P., GAO B.B., LI W.H., ZHU M., ZHENG C.F., ZHENG Q.S., WANG C.H. Physiological and biochemical responses of Ulva prolifera and Ulva linza to cadmium stress. Sci. World J. 2013, 1, 2013.

29. TRACHOOTHAM D., ALEXANDRE J., HUANG P. Targeting cancer cells by ROS-mediated mechanisms: a radical therapeutic approach? Nature Rev. Drug Discovery, 8, 579, 2009.

30. PIETRINI F., IANNELLI M.A., MONTANARI R., BIANCONI D., MASSACCI A. Cadmium I nteraction with thiols and photosynthesis in higher plants. In A. H. Jodhpur. (Ed.) Advances in Plant Physiology, India: Scientific Publishers. 8, 313, 2005 
31. WANG F., CHEN F., CAI Y., ZHANG G.P., WU F.B. Modulation of Exogenous Glutathione in Ultrastructure and Photosynthetic Performance Against Cd Stress in the Two Barley Genotypes Differing in Cd Tolerance. Biol. Trace Ele. Res. 144, 1275, 2011.

32. SEREGIN I.V., IVANOV V.B. Physiological aspects of cadmium and lead toxic effects on higher plants. Russ. J. Plant Physiol. 48, 523, 2001.

33. PIETRINI F., ZACCHINI M., IORI V., PIETROSANTI L., BIANCONI D., MASSACCI A. Screening of poplar clones for cadmium phytoremediation using photosynthesis, biomass and cadmium content analyses. Int. J. Phytoremed. 12, 105, 2010.

34. SHEN D.Y., YANG W.Q., ZHANG J., ZHOU L.Q., WU, F.H. Effects of cadmium on photosynthetic characters and biomass production of A poplar (Populus deltoids $\times$ Populus nigra). J. Sichuan Agr. Univ. 28, 61, 2010.

35. NADA E., FERJANI B.A., ALI R., IMED B.R.B.M., MAKKI B. Cadmium-induced growth inhibition and alteration of biochemical parameters in almond seedlings grown in solution culture. Acta Physil. Plant. 29, 57, 2007.

36. BAKER N.R., ROSENQUIST E. Applications of chlorophyll fluorescence can improve crop production strategies: an examination of future possibilities. J. Exp. Bot. 55, 1607, 2004.

37. MAXWELL K., JOHNSON G.N. Chlorophyll fluorescence - a practical guide. J Exp. Bot. 51, 659, 2000.

38. BERTRAND M., POIRIER I. Photosynthetic organisms and excess of metals. Photosynthetica 43, 345, 2005.

39. KHAN M.I.R., KHAN N.A. Ethylene reverses photosynthetic inhibition by nickel and zinc in mustard through changes in PS II activity, photosynthetic nitrogen use efficiency, and antioxidant metabolism. Protoplasma DOI 10.1007/s00709-014-0610-7, 2014.

40. SKORZYNSKA-POLIT E., DRAZKIEWICZ M., KRUPA Z. Lipid peroxidation and oxidative response in Arabidopsis thaliana exposed to cadmium and copper. Acta Plant Physiol. 32, 169, 2010.

41. ROMANOWSKA E., WASILEWSKA W., FRISTEDT R., VENER A.V., ZIENKIEWICZ M. Phosphorylation of PSII proteins in maize thylakoids in the presence of $\mathrm{Pb}$ ions. $\mathrm{J}$. Plant Physiol. 169, 345, 2012.

42. PIETRINI F., ZACCHINI M., IORI V., PIETROSANTI L., BIANCONI D., MASSACCI A. Spatial distribution of cadmium in leaves and its impact on photosythesis: examples of different strategies in willow and poplar clones. Plant Biol. 12, 355, 2010.

43. CHOUDHURY S., PANDA S.K. Toxic effects, oxidative stress and ultrastructural changes in moss Taxithelium nepalense (Schwaegr.) Broth. under chromium and lead phytotoxicity. Water Air Soil Poll. 167, 73, 2005.

44. BI Y.H., CHEN W.L., ZHANG W.N., ZHOU Q., YUN L.J., XING D. Production of reactive oxygen species, impairment of photosynthetic function and dynamic changes in mitochondria are early events in cadmiuminduced cell death in Arabidopsis thaliana. Biol. Cell 101, 629, 2009.

45. DALLA VECCHIA F., LA ROCCA N., MORO I., DE FAVERI S., ANDREOLI C., RASCIO N. Morphogenetic, ultrastructural and physiological damages suffered by submerged leaves of Elodea canadensis exposed to cadmium. Plant Sci. 168, 329, 2005.

46. ESPOSITO S., SORBO S., CONTE B., BASILE A. Effects of heavy metals on ultrastructure and HSP70s induction in the aquatic moss Leptodictyum riparium Hedw. Int. J. Phytoreme. 14, 443, 2012.

47. GALLEGO S.M., BENAVIDES M.P., TOMARO M.L. Effect of heavymetal ion excess on sunflower leaves: evidence for involvement of oxidative stress. Plant Sci. 121, $151,1996$.

48. RAUSER W.E., SAMARAKOON, A.B. Vein loading in seedlings of Phaseolus vulgaris exposed to excess cobalt, nikel and zinc. Plant Physiol. 65, 578, 1980.

49. MOLAS J. Changes of chloroplast ultrastructure and total chlorophyll concentration in cabbage leaves caused by excess of organic Ni(II) complexes. Environ. Exp. Bot. 47, 115, 2002.

50. HERMLE S., VOLLENWEIDE P., GÜNTHARDTGOERG M.S., MCQUATTIE C.J., MATYSSEK R. Leaf responsiveness of Populus tremula and Salix viminalis to soil contaminated with heavy metals and acidic rainwater. Tree Physiol. 27, 1517, 2007.

51. DEFILIPPIS L.F., ZIEGLER H. Effect of sublethal concentrations of zinc, cadmium and mercury on the photosynthetic carbon reduction cycle of euglena. J. Plant Physiol. 142, 167, 1993.

52. DJEBALI W., ZARROUK M., BROUQUISSE R., EL KAHOUI S., LIMAM F., GHORBEL M.H., CHAÏBI W. Ultrastructure and lipid alterations induced by cadmium in tomato (Lycopersicon esculentum) chloroplast membranes. Plant Biol. 7, 358, 2005.

53. HAKMAOUI A., ATERA M., BÓKAB K., BARÓNC M. Copper and cadmium tolerance, uptake and effect on chloroplast ultrastructure: Studies on Salix purpurea and Phragmites australis. Zeitschrift Fur Naturforschung C-A J. Biosci. 62, 417, 2007.

54. GE W., JIAO Y.Q., SUN B.L., QIN R., JIANG W.S., LIU D.H. Cadmium-mediated oxidative stress and ultrastructural changes in root cells of poplar cultivars. S. Afr. J. Bot. 83, 98, 2012. 
